\title{
Epidemiological overview of HIV/AIDS in pregnant women from a state of northeastern Brazil
}

\author{
Panorama epidemiológico do HIV/aids em gestantes de um estado do Nordeste brasileiro \\ Panorama epidemiológico del VIH/sida en mujeres embarazadas de un estado de Noreste brasileño
}

\author{
Claúdia Mendes da Silva',"I, Regina de Souza Alves", Tâmyssa Simões dos Santos"', \\ Gabriela Rodrigues Bragagnollo"v , Clodis Maria Tavaresv, Amuzza Aylla Pereira dos Santosv \\ ' Universidade Federal de Alagoas, University Hospital Professor Alberto Antunes, Multiprofessional Residency \\ Program in Adult and Older Adult Health. Maceió, Alagoas, Brazil \\ "Sociedade de Ensino Universitário do Nordeste, Bachelor of Nursing. Maceió, Alagoas, Brazil. \\ "I' Centro Universitário Mauricio de Nassau, Nursing Course. Maceió, Alagoas, Brazil. \\ Iv Universidade de São Paulo, Escola de Enfermagem de Ribeirão Preto, Graduate Program in Nursing. \\ Ribeirão Preto, São Paulo, Brazil. \\ ${ }^{v}$ Universidade Federal de Alagoas, School of Nursing and Pharmacy. Maceió, Alagoas, Brazil.
}

\section{How to cite this article:}

Silva CM, Alves RS, Santos TS, Bragagnollo GR, Tavares CM, Santos AAP. Epidemiological overview of HIV/AIDS in pregnant women from a state of northeastern Brazil. Rev Bras Enferm [Internet]. 2018;71(Suppl 1):568-76. [Thematic Issue: Contributions and challenges of nursing practices in collective health] DOI: http://dx.doi.org/10.1590/0034-7167-2017-0495

Submission: 07-06-2017

Approval: 10-09-2017

\section{ABSTRACT}

Objective: To learn the epidemiological characteristics of HIV infection in pregnant women. Method: Descriptive study with quantitative approach. The study population was composed of pregnant women with HIV/AIDS residing in the state of Alagoas. Data were organized into variables and analyzed according to the measures of dispersion parameter relevant to the arithmetic mean and standard deviation $(X \pm$ S). Results: Between 2007 and 2015, 773 cases of HIV/AIDS were recorded in pregnant women in Alagoas. The studied variables identified that most of these pregnant women were young, had low levels of education and faced socioeconomic vulnerability. Conclusion: It is necessary to include actions aimed at increasing the attention paid to women, once the assurance of full care and early diagnosis of HIV are important strategies to promote adequate treatment adherence and reduce the vertical transmission. Descriptors: Pregnant Women; HIV Seropositivity; Epidemiology; Attention to Health; Nursing.

\section{RESUMO}

Objetivo: Conhecer as características epidemiológicas da infecção pelo HIV em gestantes. Método: Estudo descritivo com abordagem quantitativa. A população estudada foi composta por gestantes com HIV/aids residentes no estado de Alagoas. Os dados foram organizados em variáveis e analisados segundo o parâmetro de medidas de dispersão pertinentes à média aritmética e ao desvio padrão $(X \pm$ S). Resultados: No período de 2007 a 2015 foram registrados 773 casos de HIV/aids em gestantes em Alagoas. As variáveis estudadas identificaram que a maioria dessas gestantes engloba mulheres jovens, com baixos níveis de instrução e situação socioeconômica de vulnerabilidade. Conclusão: Para tanto, faz-se necessário a inclusão de ações direcionadas a ampliação da atenção às mulheres, em que a garantia de atendimento integral e diagnóstico precoce do HIV constituem estratégias importantes para promover adequada adesão ao tratamento e a redução da transmissão vertical.

Descritores: Gestantes; Soropositividade para HIV; Epidemiologia; Atenção à Saúde; Enfermagem.

\section{RESUMEN}

Objetivo: Conocer las características epidemiológicas de la infección por el VIH en mujeres embarazadas. Método: Estudio descriptivo con el abordaje cuantitativo. La población estudiada fue compuesta por mujeres embarazadas con VIH/sida residentes en el estado de Alagoas. Los datos fueron organizados en variables y analizados según el parámetro de medidas de dispersión pertinentes a la media aritmética y al desvío estándar $(X \pm$ S). Resultados: En el período de 2007 a 2015 fueron registrados 773 casos de VIH/sida en mujeres embarazadas en Alagoas. Las variables estudiadas identificaron que la gran parte de esas mujeres embarazadas engloba a mujeres jóvenes, 
con bajos niveles de instrucción y situación socioeconómica de vulnerabilidad. Conclusión: Para ello, se hace necesaria la inclusión de acciones direccionadas a ampliación de la atención a las mujeres, en que la garantía de atención integral y el diagnóstico precoz del VIH constituyen estrategias importantes para promocionar la adecuada aceptación al tratamiento y la reducción de la transmisión vertical.

Descriptores: Mujeres Embarazadas; Seropositividad para VIH; Epidemiologia; Atención a la Salud; Enfermería.

CORRESPNDING AUTHOR Claúdia Mendes da Silva E-mail: claudiamendescm@hotmail.com

\section{INTRODUCTION}

The growth in the number of cases of infection by the Human Immunodeficiency Virus (HIV) is a global phenomenon that represents important epidemiological changes, marked by the phenomena of "feminization," "interiorization," "pauperization" and "juvenilization"(1-3).

In Brazil, of the 15,885 AIDS cases diagnosed since their discovery until present days, 5,001 correspond to women, who are responsible for a percentage of $31.5 \%$ of total cases in Brazil(4). In this scenario, considering the state of Alagoas, we noticed that the first HIV cases in women date back to 1987, when the average was seven men infected for every woman. Over the years and with the significant increase in cases in the female population, the number of new cases has reached a total of 237 men infected with HIV for 139 women in $2012^{(5)}$.

In line with the Brazilian reality, the increase in cases of women infected with HIV is a problem in several Latin American countries, mainly in Dominican Republic, Argentina and El Salvador, where sex tourism, socioeconomic conditions and the influence of power dynamics and gender roles were associated with this overview ${ }^{(6)}$. In this sense, because the increased transmission of HIV by heterosexual contact has led to the substantial growth of cases in women, especially in the reproductive age, we observe that the feminization of AIDS became the most worrisome phenomenon for the current framework of this epidemic, considering the real possibilities of mother-to-child transmission of $\mathrm{HIV}^{(7)}$.

According to the Ministry of Health ${ }^{(4)}$, the detection rate of pregnant women with HIV in Brazil has been showing a trend of increase in the last ten years; whereas in 2006 the rate observed was 2.1 cases per 1,000 LB, in 2015, this value passed to 2.7 , indicating an increase of $28.6 \%$. In the state of Alagoas, the incidence rate was 2.5 per 1,000 LB in 2015, which demonstrates proximity to the national average.

In this context, estimates indicate that, each year, approximately 17,200 pregnant women are infected with HIV, which makes the vertical transmission responsible for almost all cases of the infection in children under the age of 13 years ${ }^{(8)}$. However, we believe the indicators of HIV in pregnant women can be improved with the implementation of preventive actions proposed in Rede Cegonha (Stork Network) by the Federal Government. This proposal, which aims to improve the quality of prenatal and birth care, recommends, in addition to the availability of fast tests as a strategy for early HIV detection and treatment, the universal offer of antiretroviral therapy for pregnant women during pregnancy and delivery, and for newborns in the first weeks of life $\mathrm{e}^{(9)}$.

However, a study conducted in Piauí( ${ }^{(7)}$, aimed at the identification of the epidemiological profile of HIV-positive pregnant women attended at a state maternity, identified several difficulties faced by health services regarding the incorporation of such prophylactic measures, in which the socioeconomic conditions of pregnant women, as well as the deficiencies in the healthcare system, constituted important obstacles in these women's adherence to prenatal care and, consequently, to treatment.

Judging by the specifics the HIV/AIDS epidemic present among different population segments, it is necessary to incorporate appropriate coping strategies to the situational context this population is inserted. To this end, to know the epidemiological characteristics of pregnant women with HIV is essential to create actions that effectively improve the quality of care for these women.

\section{OBJECTIVE}

We believe it is important to learn the epidemiological characteristics of HIV infection in pregnant women.

\section{METHOD}

\section{Ethical aspects}

This study did not need to be appreciated by the Research Ethics Committee, as Resolution 466/2012 of the National Health Council, because the results are related to public access databases of the State Secretariat of Health of the state of Alagoas (SESAU).

\section{Design, study location, population and period}

This is a descriptive epidemiologic study with quantitative approach.

Descriptive epidemiology studies the incidence and/or prevalence of a disease, observing how it relates to certain characteristics, such as: sex, age, education, occupation, income, among others. This way, the researcher is not only capable of identifying situations and/or risk groups for prevention purposes; she/ he also becomes capable of visualizing possible hypotheses for future research. Regarding the descriptive studies, these are intended to determine the distribution of diseases or healthrelated conditions, according to individuals' time, place and/or characteristics $^{(10)}$.

The study was carried out in the state of Alagoas, which is located in northeastern Brazil, with a population, in 2016, of $3,358,963$ inhabitants. The nominal monthly household income per capita of the resident population reaches $\mathrm{R} \$ 662$, while the Human Development Index (HDI) is the worst in the country, reaching $0.68^{(11)}$. The study population was composed of pregnant women with HIV/AIDS, residents in the state of Alagoas, who were notified in the period from 2007 to 2015. 


\section{Study protocol}

Data collection was carried out from May 2016 to April 2017 through the Epidemiological Surveillance database, available in the Secretariat of Health of São Paulo (SES), as well as the System for Notifiable Diseases (SINAN) and Information System on live births (SINASC), provided by the Department of Informatics of the Brazilian Unified Health System - DATASUS regarding the total number of cases of pregnant women with HIV/AIDS notified in Alagoas.

The data collected were organized from epidemiological variables divided into three typologies: sociodemographic (age, race/color, and education), health (year of diagnosis and birth year) and access to health services (prenatal and serological evidence period).

\section{Results analysis and statistics}

The numbers were exported to the software Tabwin 2.7, being tabulated and compiled into the software Microsoft Excel 2016 for Windows ${ }^{\circledR}$. The incidence coefficients were obtained from the number of HIV cases detected in pregnant women living in Alagoas in the given period, divided by the total number of live births residing in the same place and year of notification, with demographic information available through demographic censuses.

Subsequently, data were submitted to descriptive analysis, through the measures of dispersion parameter, using the arithmetic mean and standard deviation $(X \pm S)$, seeking to arrange the variability of the data. Following the measurement, the data were presented in graphs and table through absolute and relative frequency, as well as detection coefficient (or rate).

\section{RESULTS}

Considering the variables studied, in the period between 2007 and 2015, 773 cases of pregnant women with HIV/ AIDS were identified in the state of Alagoas. Table 1 shows that $31.2 \%$ of the pregnant women declared from 5 to 8 years of schooling $(X=30.5$ and $S=8.6)$, while $7.4 \%$ of them did not attend school $(X=3.2$ and $S=7.7)$ and $1.9 \%$ presented 12 years or more of schooling.

Concerning these women's age group, the group from 20 to 34 years showed the highest percentage of cases, with $70.9 \%$ $(X=71.8$ and $S=6.4)$, followed by the age group from 15 to 19 years, with percentage of $18.6 \%(X=18.3$ and $S=5.8)$. We also highlight the cases of pregnant women with HIV/AIDS in the age group below 15 years, which recorded 12 cases in the study period, totaling a percentage of $1.5 \%(X=1.4$ and $S=0.9)$.

Regarding the variable race/color, we can infer that $72.1 \%$ of pregnant women have declared themselves as being mixedrace, which is the phenotype responsible for the highest number of cases during the period $(X=72.1$ and $S=5.6)$, followed by the white color, with $11.8 \%(X=12.2$ and $S=3.5)$. On the other hand, we observed an increase in cases of race/black color, which are reaching the second position in some of the years studied, showing percentage of $10.6 \%(X=10.1$ and $S=5.6)$.

Regarding the progress of the cases, the detection rate of pregnant women with HIV/AIDS in the state of Alagoas has been showing a tendency of increase in recent years $(X=1.7$ $\mathrm{S}=0.5$ ). Figure 1 shows a rate of 1.0 case/1,000 live births in 2007, which passed to 2.5 in 2015, being the year with the largest rate in the study period after increase of $150 \%$.

Table 1 - Distribution of HIV/AIDS cases in pregnant women according to sociodemographic data, Alagoas, Brazil, 2007 to 2015

\begin{tabular}{|c|c|c|c|c|c|c|c|c|c|c|}
\hline Variables & $\begin{array}{l}2007 \\
\text { n(\%) }\end{array}$ & $\begin{array}{l}2008 \\
\text { n(\%) }\end{array}$ & $\begin{array}{l}2009 \\
n(\%)\end{array}$ & $\begin{array}{l}2010 \\
n(\%)\end{array}$ & $\begin{array}{l}2011 \\
\text { n(\%) }\end{array}$ & $\begin{array}{l}2012 \\
\mathrm{n}(\%)\end{array}$ & $\begin{array}{l}2013 \\
\text { n(\%) }\end{array}$ & $\begin{array}{l}2014 \\
\text { n(\%) }\end{array}$ & $\begin{array}{l}2015 \\
\text { n(\%) }\end{array}$ & $X^{*} \underset{\mathrm{n}}{ \pm} S^{* *}$ \\
\hline \multicolumn{11}{|l|}{ Schooling } \\
\hline Ign***/blank & $8(16)$ & $10(13.7)$ & $8(11.4)$ & $21(27.6)$ & $22(26.5)$ & $8(11)$ & 20(19.2) & 21(18.1) & $27(21.1)$ & $18.3 \pm 6.0$ \\
\hline None & $5(10)$ & $8(10.9)$ & $9(12.9)$ & $5(6.6)$ & $6(7.2)$ & $2(2.7)$ & $9(8.6)$ & $6(5.2)$ & $7(5.5)$ & $7.7 \pm 3.2$ \\
\hline From 1 to 4 & $13(26)$ & $34(46.6)$ & $18(23.7)$ & 18(23.7) & $21(25.3)$ & $19(26)$ & 20(19.2) & $26(22.4)$ & $22(17.2)$ & $25.8 \pm 8.4$ \\
\hline From 5 to 8 & $14(28)$ & $9(12.3)$ & $21(30)$ & $25(32.9)$ & $22(26.5)$ & $31(42.5)$ & $34(32.7)$ & $34(29.3)$ & $51(39.8)$ & $30.5 \pm 8.6$ \\
\hline From 9 to 11 & $9(18)$ & $8(11)$ & $10(14.3)$ & $7(9.2)$ & $10(12.1)$ & $12(16.4)$ & 19(18.3) & $28(24.1)$ & $21(16.4)$ & $15.5 \pm 4.5$ \\
\hline From 12 and more & $1(2)$ & $4(5.5)$ & $4(5.7)$ & $0(0.0)$ & $2(2.4)$ & $1(1.4)$ & $2(2)$ & $1(0.9)$ & $0(0.0)$ & $2.2 \pm 2.1$ \\
\hline \multicolumn{11}{|l|}{ Age group } \\
\hline$>15$ years & $0(0)$ & $1(1.4)$ & $0(0)$ & $1(1.3)$ & $1(1.2)$ & $1(1.4)$ & $3(2.9)$ & $2(1.7)$ & $3(3.2)$ & $1.4 \pm 0.9$ \\
\hline 15 to 19 years & $5(10)$ & $12(16.4)$ & $16(22.9)$ & $16(21.1)$ & 13(15.7) & $18(24.6)$ & 11(10.6) & $20(17.2)$ & $33(25.8)$ & $18.3 \pm 5.8$ \\
\hline 20 to 34 years & $42(84)$ & $55(75.3)$ & $49(70)$ & $50(65.8)$ & $62(74.7)$ & $50(68.5)$ & 80(76.9) & $78(67.3)$ & $82(64.1)$ & $71.8 \pm 6.4$ \\
\hline 35 to 49 years & $3(6)$ & $5(6.9))$ & $5(7.1)$ & $9(11.8)$ & $7(8.4)$ & $4(5.5)$ & $10(9.6)$ & 16(13.8) & 10(7.8) & $8.5 \pm 2.7$ \\
\hline \multicolumn{11}{|l|}{ Race/Color } \\
\hline Ign $* * * /$ blank & $4(8)$ & $3(4.1)$ & $3(4.3)$ & $4(5.3)$ & $4(4.8)$ & $3(4.1)$ & $3(2.9)$ & $6(5.2)$ & $6(4.7)$ & $4.8 \pm 1.4$ \\
\hline White & $6(12)$ & $7(9.6)$ & $11(15.7)$ & $9(11.8)$ & 14(16.9) & $11(15.1)$ & $14(13.5)$ & $7((6)$ & $12(9.4)$ & $12.2 \pm 3.5$ \\
\hline Black & $5(10)$ & $5(6.8)$ & $2(2.9)$ & $4(5.3)$ & $7(8.4)$ & $14(19.2)$ & $8(7.7)$ & $21(18.1)$ & $16(12.5)$ & $10.1 \pm 5.6$ \\
\hline Yellow & $0(0.0)$ & $0(0.0)$ & $0(0.0)$ & $1(1.3)$ & $1(1.2)$ & $0(0.0)$ & $0(0)$ & $2(1.7)$ & $1(0.8)$ & $0.6 \pm 0.7$ \\
\hline Mixed-race & $35(70)$ & $58(79.5)$ & $54(77.1)$ & $58(76.3)$ & $57(68.7)$ & $45(61.6)$ & $78(75)$ & $79(68.1)$ & $93(72.6)$ & $72.1 \pm 5.6$ \\
\hline Indigenous & $0(0)$ & $0(0)$ & $0(0)$ & $0(0)$ & $0(0)$ & $0(0)$ & $1(0.9)$ & $1(0.9)$ & $0(0)$ & $0.2 \pm 0.4$ \\
\hline
\end{tabular}

Source: SINAN/SINASC/SES/AL, 2017.

Notes: *Arithmetic mean; ${ }^{*}$ Standard deviation; ***Ignored. 


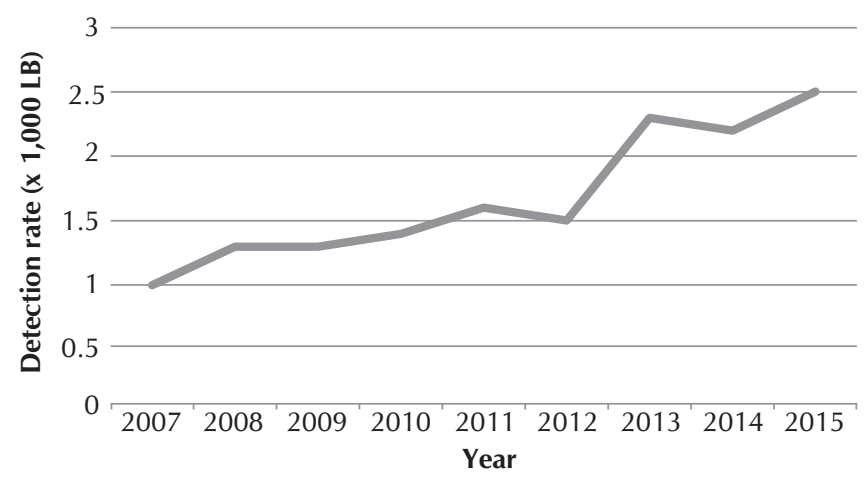

Source: SINAN/SES/AL, 2017.

Figure 1 - Detection rate of HIV/AIDS in pregnant women (per 1,000 live births), according to the birth year, Alagoas, Brazil, 2007 to 2015

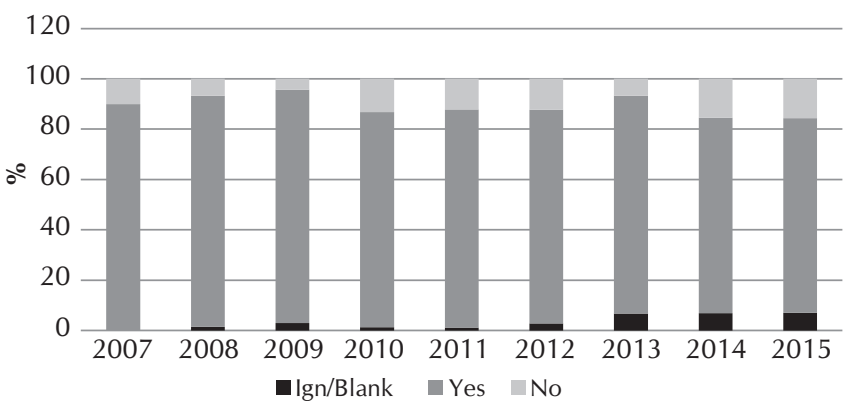

Source: SINAN/SES/AL, 2017.

Note: Ign. = Ignored.

Figure 2 - Relative Frequency (\%) of HIV/AIDS in pregnant women, according to prenatal care and birth year, Alagoas, Brazil, 2007 to 2015

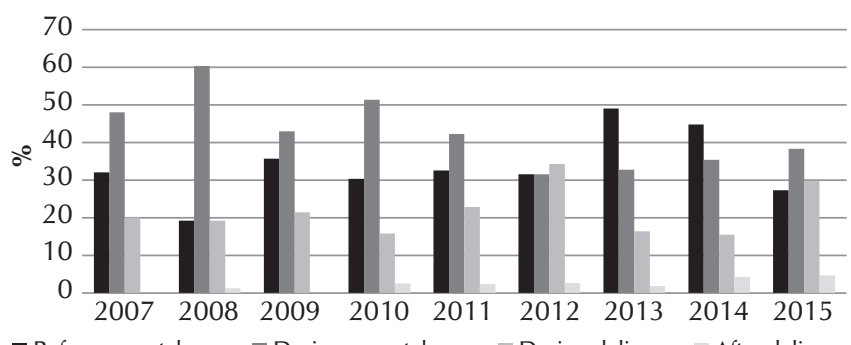

- Before prenatal care During prenatal care During delivery After delivery

Source: SINAN/SES/AL, 2017.

Figure 3 - Absolute Frequency of HIV/AIDS in pregnant women, according to serological evidence of HIV, Alagoas, Brazil, 2007 to 2015

The proportional distribution of the pregnant women who got the prenatal care shows a percentage relatively balanced among the years, with $84.7 \%$ for those who attended at least one prenatal appointment $(X=85.9$ and $S=5.5)$ and $11.3 \%(X=10.7$ and $\mathrm{S}=4.0$ ) for those who did not get the prenatal care (Figure 2).

Whereas the serological evidence, Figure 3 shows that the percentage of pregnant women who had access to the diagnosis during prenatal care was the highest in most years, with $41.3 \% \quad(X=42.5$ and $S=9.4)$. Serological evidence before prenatal care accounted for $34.4 \%$ of the number of cases, with the years 2013 and 2014 being leaders in notifications $(\mathrm{X}=33.6, \mathrm{~S}=8.9)$. The percentage of pregnant women with a diagnosis of HIV during delivery occupied the first position in 2012, when accounted for $34.2 \%$ of the cases that year $(X=21.7$ and $S=6.5)$; and the diagnosis after delivery presented the lowest occurrence, with $2.6 \%(X=2.2$ and $S=1.6)$.

\section{DISCUSSION}

Although the compulsory notification of HIV-seropositive pregnant women had been introduced into Brazil since the year 2000, in Alagoas, until 2007, a timid process of records caused by deficiencies in the healthcare system could be observed $^{(12)}$.

Considering the variables, we can observe that schooling presented the greatest percentage of cases in groups with eight or fewer years of schooling. Similarly, a study conducted at the University Hospital of Santa Maria (RS) found that $65 \%$ of the pregnant women infected with HIV had low level of schooling ${ }^{(13)}$. Identical situation occurred in Passos (MG), in which authors showed low level of schooling in $80 \%$ of the women studied ${ }^{(14)}$. In this regard, studies on HIV-positive pregnant women conducted in Brazil found that the majority of these women had a low level of schooling ${ }^{(15)}$. However, when evaluating this scenario in Spain, researchers reported that most women infected with HIV (75.2\%) claimed to have secondary education ${ }^{(16)}$. These findings can be justified by the fact that the European countries have a better planning and higher investments in the educational area ${ }^{(17)}$.

In this sense, the level of schooling has been used as an important indicator analogous to socioeconomic variables. This way, the increase in AIDS cases in individuals with lower level of education has been an indicative the epidemic is spreading to disadvantaged layers of society, described as pauperization $^{(18)}$.

Regarding age, the ones between 20 and 29 years are the most affected. This result is similar to data found by authors who developed a study at Hospital das Clínicas of the University of São Paulo (USP), identifying an average of 28.9 years and predominance from 25 to 34 years $^{(19)}$. In the same way, a research conducted at the University Hospital of Rio de Janeiro showed an age group from 30 to 34 years $^{(20)}$. On the other hand, in the state of Pará, a reference service in Women's and Children's Health evaluated mostly young people aged between 18 and 23 years ${ }^{(21)}$.

In Brazil, the age group most affected by HIV/AIDS in women is between 25 and 39 years ${ }^{(22)}$. As to Latin American countries, there are differences regarding age group. In Chile ${ }^{(23)}$, a prevalence of infected pregnant women was identified between 14 and 24 years; in Colombia ${ }^{(24)}$, most women were in reproductive phase (15 to 49 years); however, the percentage of pregnant women infected in this study was low, reaching a percentage of $1 \%$. At the same time, a survey conducted in Argentina found a reduction in the incidence of HIV-infected women in the reproductive age ${ }^{(25)}$, and in Honduras, the average age was 26 years and the reproductive age range was evidenced with ages ranging from 19 to 38 years ${ }^{(26)}$. 
The growth of pregnant women with HIV/AIDS aged between 15 and 19 years must be highlighted. In this sense, the authors argue that the emergence of this disease among adolescents may be linked to several factors, such as: greater vulnerability in the adolescent phase, low socioeconomic status, lower education, difficulty of access to Primary Health Care Units (UAPS); and they report that this group is more likely to risk situations, such as the use of alcohol, drugs, unintended pregnancy, violence and STI/HIV/AIDS ${ }^{(27)}$.

Thus, when evaluating the increase in cases of pregnant teenagers with HIV/AIDS, it is possible to question whether they were properly oriented about contraception methods and the prevention of STIs, since the abandonment of this population by the health system would constitute a violation against the sexual, reproductive and health rights of these individuals. Instead, the National Policy for Integral Attention to Women's Health (PNAISM) ensures the advances related to sexual and reproductive rights and establishes the issues concerning prevention and treatment of women living with HIV/AIDS ${ }^{(28)}$. Above all, we realize the importance and necessity of public policies and sexual health programs in schools that aim to contribute to the proper education of adolescents, so they can be aware and take decisions regarding their sexuality ${ }^{(29)}$. Nurses, as health professionals, work in several areas, such as preventive and curative care and in health education, the health of adolescents is an interface of their practice ${ }^{(30)}$.

In this context, the nurse plays a key role as an educator/facilitator committed to using education strategies in health, in an attempt to change risk behavior ${ }^{(31)}$; in addition, the nurse also plays a key role regarding family planning, since he/she is the one who performs the anamnesis, the physical and gynecological exam, investigates current complaints, reproductive goals and knowledge about contraceptive methods, strengthens the importance of family planning, orients about the method chosen, about sexual and reproductive health, among others ${ }^{(32)}$.

As for instruments that can be used, the Integrated Plan to Combat the Feminization of AIDS and other STIs and the School Health Programme (PSE) are positive strategies to guide the actions and plans of health professionals for a more integrated care to adolescents and HIV-infected women ${ }^{(31)}$.

As for the racial distribution of pregnant women, we observed that the sum of the mixed-race and black color in 2015 is equivalent to $85.1 \%$. In Brazil, racism is still strongly present in individuals' lives, being seen mostly in communities that suffer from pauperization ${ }^{(33)}$. The vulnerability of the black population to HIV/AIDS, invisibility and sexual violence against women contributes to the growth of cases. Considering the exposed, health promotion strategies for this group are essential concerning the prevention of opportunistic infections, use of antiretroviral therapies (HAART), and easy access to health services. To do so, it is urgent to define black women as priority population in the public policies of STI/AIDS ${ }^{(34)}$.

To analyze the evolution of the cases of HIV-infected pregnant women, we observed an important phenomenon for the current time of the AIDS epidemic in Brazil, which, for decades, was linked to homosexuality; however, its dissemination reached various social segments. For years, groups and/or risk behavior were described, but nowadays, they report a framework marked by heterosexualization and feminization processes ${ }^{(35-37)}$.

This new scenario demands the recognition of the vulnerability conditions of women to HIV ${ }^{(12)}$. Authors highlight economic and psychosocial aspects and gender relations as important factors connected with this reality ${ }^{(38)}$. Similar results are seen in Latin American countries, which occupy the 4th place in number of cases; while the Western Europe and North American countries are in the last position. Therefore, this overview is related to the social and economic situation of these populations, since the Latin American countries are considered underprivileged ${ }^{(39)}$.

According to an epidemiological survey of the State Secretariat of Health of Alagoas, in 2012, the municipalities: Coqueiro Seco, Flexeiras and Joaquim Gomes showed higher rates of pregnant women with HIV/AIDS than the capital city Maceió(40). The increase in these rates in small- and medium-sized municipalities reflects the phenomenon of interiorization that AIDS epidemic has been showing across the country, striking heavily those who live in underserved communities ${ }^{(41)}$. The interiorization event in Alagoas can be characterized because of the low coverage of the Family Health Strategy (ESF) in the inner cities. Basic Health Units (UBS) have several problems, such as: inadequate physical structure of services, insufficiency and profile of health professionals, erratic monitoring and evaluation of the actions, being, this way, a policy in construction $^{(42)}$.

As for the prenatal care of pregnant women with HIV/AIDS, despite the increasing adherence of these women to prenatal care throughout the study period, the percentage of those who did not get prenatal care may be associated with the ignorance of their condition, as well as to weaknesses in the active search for health a system. A study developed in southern Brazil showed that almost $70 \%$ of pregnant women have their diagnosis in the gestation period during prenatal appointments; therefore, when the beginning of these appointments are delayed or occurs in insufficient number, they constitute barriers to the prevention of mother-to-child transmission of HIV ${ }^{(43)}$.

In Fortaleza, the authors noticed that pregnant women who discovered HIV early on began antiretroviral treatment more quickly, showing the importance of early diagnosis for more effective compliance. For this reason, to provide tests in previous steps of pregnancy is essential, that is, to stimulate and disseminate family planning programs, which, certainly, will contribute to the prevention of vertical transmission and Sexually Communicable Diseases (STDs) ${ }^{(44)}$.

Data showed that women's access to diagnosis of HIV infection took place, mostly, during prenatal care, which reinforces the importance of this medical follow-up for the pregnant woman. In a study conducted at the Hospital das Clínicas of the Federal University of Minas Gerais, similar results were observed, in which $60 \%$ of pregnant women had discovered the diagnosis during the prenatal serological screening or at time of delivery and, according to the analysis of these results, the knowledge of positive serology for HIV test triggered a series of reactions and had a negative impact on the lives of pregnant women, since in general, these women did not perceive themselves vulnerable to HIV, which led, initially, to feelings of indignation, remorse, sadness and indifference ${ }^{(45)}$. 
This way, even if the proposed interventions reduce, significantly, mother-to-child transmission of HIV, in Brazil, the coverage of prophylactic actions is still low because of various obstacles, such as lack of prenatal care or inappropriate assistance, late diagnosis of HIV and low women's adherence to recommendations ${ }^{(46)}$.

The policy of prevention and attention to HIV is known worldwide as sets of actions established and developed aiming stabilization. "New objectives related to HIV/AIDS epidemic have been predetermined worldwide at a meeting of the United Nations (UN), in which Brazil participated"(44). At this meeting, the member States of the UN report, in a statement, the commitment for 2020 to reduce new infections of HIV and the mortality rates of AIDS to less than 500 thousand a year. Some preventative measures are: realization of elective cesarean section, zidovudine monotherapy (AZT), antiretroviral management, administration of AZT during delivery and use of oral antiretroviral by the newborn exposed during birth until the 42nd day of life, and replacement of natural breastfeeding by bottle-feeding ${ }^{(47-49)}$.

From the data collection we noticed that it is of paramount importance to offer services to these infected people because of the socioeconomic profile presented, composed mainly of black and mixed-race women with low level of schooling who need to be assisted in contraception and prevention of sexual transmitted infections. Defending this hypothesis, the coverage of prophylactic actions in Brazil is still low because of various obstacles, such as lack of prenatal care or inadequate assistance, late diagnosis of HIV and low adherence of women to the recommendations ${ }^{(50)}$.

\section{Study limitations}

Among the limitations of this study we include the information classified as ignored/blank, which triggers potential flaws in the research. In addition, even though estimates of new cases are higher than those reported in the state of Alagoas, we could assume that cases were sub-notified. These limitations could compromise the epidemiological analyses.

\section{Contributions to the fields of Nursing, Health, or Public Policies}

This study pointed out the growing feminization of AIDS in the state of Alagoas and some interfaces that constitute the epidemiological overview of HIV/AIDS in pregnant women. Thus, this study will contribute to the reflection of health professionals, especially nurses, who need to be mindful of the psychological, biological, clinical and social demands of people living and dealing with HIV/AIDS, because the nurse responds directly by the prenatal care, which aims to ensure the quality of care and early discovery of diseases that may affect these women in the gravid-puerperal cycle and that, many times, for not being able to assist them properly, contribute to negative outcomes that increase the maternal-infant morbidity and mortality rates. In this context, HIV/AIDS in the gravidpuerperal cycle can be monitored by a nurse through the actions advocated by the Stork Network, guaranteeing fast tests so that pregnant women can be diagnosed and treated as early as possible, favoring thus the reduction of maternal mortality coefficients and vertical transmission of HIV.

\section{CONCLUSION}

From the results of the epidemiological overview of HIV/ AIDS in pregnant women, we can observe that most pregnant women with HIV/AIDS in the state of Alagoas are young women with low level of education and vulnerable socioeconomic status who attended at least one prenatal appointment and whose diagnosis of HIV occurred mostly during the prenatal period.

We should highlight that this study enabled a more critical and singular overview of HIV/AIDS in the state of Alagoas, since there is the need to improve public policies that meet the epidemiological changes incurred and that promote better living and health conditions to this population to minimize the damage caused to the father-mother-daughter/son trinomial.

Still considering the gravid-puerperal scope, the implementation of actions focused on the extension of assistance to women is necessary, in which the guarantee of full service, in line with early diagnosis, become important strategies for promoting adequate adhesion to the treatment and reduction of vertical transmission, including the health professional as the protagonist in the clinical decision making, providing important information for primary healthcare to pregnant women in the gravid-puerperal cycle.

According to the exposed, this overview showed that these findings may provide subsidies for a discussion on the practical assistance to the trinomial by health professionals during the prenatal period, regarding the development of educational activities that consider the peculiarities and specific needs of pregnant women, providing not only HIV prevention, but also a better quality of care in the gestation and parturition period.

\section{REFERENCES}

1. Ayala ALM, Moreira A, Francelino G. Características Socioeconômicas e Fatores Associados à Positividade para o HIV em Gestantes de uma Cidade do Sul do Brasil. Rev APS[Internet]. 2016 [cited 2017 Apr 21];19(2):210-20. Available from: https://aps. ufjf.emnuvens.com.br/aps/article/view/2570/968

2. Mombelli MA, Barreto MS, Arruda GO, Marcon SS. AIDS epidemic in the triple frontier: subsidies for professional practice. Rev Bras Enferm[Internet]. 2015 [cited 2017 May 18];68(3):429-37. Available from: http://www.scielo.br/pdf/reben/v68n3/en_00347167-reben-68-03-0429.pdf

3. Vieira ACS, Rocha MSG, Head JF, Casimiro, IMPC. A epidemia de HIV/Aids e a ação do Estado. Diferenças entre Brasil, África 
do Sul e Moçambique. Rev Katál[Internet]. 2014[cited 2017 Apr 21];(17)2:196-206. Available from: http://www.scielo.br/pdf/rk/ v17n2/1414-4980-rk-17-02-0196.pdf

4. Brasil. Ministério da Saúde. Secretaria de Vigilância em Saúde. Boletim Epidemiológico HIV - Aids [Internet]. 2016 [cited 2017 Jun 02];1(1). Available from:http://www.aids.gov.br/sites/default/files/anexos/publicacao/2016/59291/boletim_2016_1_pdf_16375.pdf

5. Alagoas. Secretaria de Saúde do Estado de Alagoas. Diretoria de Vigilância Epidemiológica. Boletim Epidemiológico: DST/Aids e Hepatites Virais[Internet]. Maceió: Secretaria de Saúde do Estado de Alagoas. 2013 [cited 2017 Jun 04]. Available from: http:// www.saude.al.gov.br/tag/vigilancia-epidemiologica/

6. Silva LR, Visgueira AF, Oliveira NL, Rocha MEMO. Variáveis epidemiológicas da infecção pelo HIV em gestantes. Rev Enferm UFPI [Internet]. 2016[cited 2017 Aug 02];5(1):34-9. Available from: http://www.ojs.ufpi.br/index.php/reufpi/article/view/3428/pdf

7. Brasil. Ministério da Saúde. Realização do Teste Rápido para HIV e Sífilis na atenção básica e aconselhamento em DST/Aids da Rede [Internet]. Brasília: Ministério da Saúde. 2012[cited 2017 Aug 02]. Available from: http://conselho.saude.gov.br/ resolucoes/2012/Reso466.pdf

8. Barcellos C, Acosta LMW, Lisboa EP, Brito MRV, Flores R. Estimate of HIV prevalence in pregnant women by means of spatial analysis in Southern Brazil. Rev Saúde Pública [Internet]. 2006 [cited 2017 Abr 21];40(5). Available from: http://www.scielo.br/ pdf/rsp/v40n5/en_cb-5349.pdf

9. Lopes ACMU, Araújo MAL, Vasconcelos LDPG, Uchoa FSV, Rocha HP, Santos JR. Implementation of fast tests for syphilis and HIV in prenatal care in Fortaleza, Ceará. Rev Bras Enferm [Internet]. 2016 [cited 2017 Aug 02].;69(1):54-8. Available from: http://www. scielo.br/pdf/reben/v69n1/0034-7167-reben-69-01-0062.pdf

10. Marconi MA, Lakatos EM. Fundamentos da Metodologia Científica. São Paulo: Atlas; 2010.

11. Brasil. Instituto Brasileiro de Geografia e Estatística - IBGE. [cited 2017 May 29]. Available from: https://cidades.ibge.gov.br/

12. Brasil. Ministério da Saúde. Secretaria de Vigilância em Saúde. Departamento de Análise de Situação em Saúde. Saúde Brasil 2013: uma análise da situação de saúde e das doenças transmissíveis relacionadas à pobreza[Internet]. Brasília: Ministério da Saúde 2014[cited 2017 Apr 21]. Available from: http://bvsms.saude.gov.br/bvs/publicacoes/saude_brasil_2014_analise_situacao.pdf

13. Konopka CK, Beck ST, Wiggers D, Silva SK, Diehl FP, Santos FG. Perfil clínico e epidemiológico de gestantes infectadas pelo HIV em um serviço do Sul do Brasil. Rev Bras Ginecol Obstet [Internet]. 2010 [cited 2017 May 29];32(4):184-90. Available from: http://www.scielo.br/pdf/rbgo/v32n4/v32n4a06.pdf

14. Souza CP, Piantino CB, Queiroz CA, Maia MAC, Fortuna CM, Andrade RD. Incidência de transmissão vertical do HIV entre gestantes soropositivas cadastradas em um serviço de referência regional. J Res: Fundam Care[Internet]. 2016 [cited 2017 Apr 21];8(2):4526-37. Available from: http://seer.unirio.br/index.php/cuidadofundamental/article/view/4964/pdf_1912

15. Ferreira LT, Mello PSM, Becker VL, Flores MC. Gestantes que tem HIV/Aids no contexto da transmissão vertical: visibilidade da produção cientifica nacional na área da saúde. Rev Pesq Cuid Fund[Internet]. 2011[cited 2017 Apr 21]. Available from: http:// www.redalyc.org/articulo.oa? id $=505750889026$

16. Hernando V, Alejos B, Montero M, Pérez-Elias Maj, Blanco JR, Giner L, et al. Reproductive history before and after HIV diagnosis: a cross-sectional study in HIV-positive women in Spain. Med[Internet]. 2017[cited 2017 Apr 21];96(5):e5991. Available from: https://www.ncbi.nlm.nih.gov/pmc/articles/PMC5293456/

17. Giffin, K, Costa SH. Questões da saúde reprodutiva[Internet]. Rio de Janeiro: Editora FIOCRUZ; 1999[cited 2017 Oct 21]. Available from: https://static.scielo.org/scielobooks/t4s9t/pdf/giffin-9788575412916.pdf

18. Galvão JMV, Costa ACM, Galvão JV. Perfil sociodemográfico de portadores de HIV/Aids de um serviço de atendimento especializado. Rev Enferm UFPI [Internet]. 2017 [cited 2016 Jun 02];6(1):04-08 Available from: http://www.ojs.ufpi.br/index.php/ reufpi/article/view/5533.

19. Pimenta ATM, Duarte G, Couto-Fernandez JC, Correa IA, Melli PPS, Quintana SM. Gestantes HIV: Características Clínicas e Sociodemográficas. Rev Atenc Saúde. 2015;13(45):20-25.

20. Assis MR, Silva LR, Lima DS, Rocha CR, Paiva MS. Conhecimento e prática sexual de gestantes HIV positivas atendidas em hospital universitário. Rev Enferm UERJ [Internet]. 2016 [cited 2017 Jun 17];24(6). Available from: http://www.e-publicacoes.uerj. br/index.php/enfermagemuerj/article/viewFile/12536/20983

21. Menezes LSH, Palácios VRCM, Alcântara MSV, Bichara CNC. Prevalência da Infecção por HIV em Grávidas no Norte do Brasil. J Bras Doenças Sex Transm [Internet]. 2012 [cited 2017 Aug 14];24(4):250-4. Available from: http://www.dst.uff.br/revista24-42012/6-Prevalencia\%20da\%20Infeccao\%20por\%20HIV\%20em\%20Gravidas.pdf

22. Brasil. Ministério da Saúde. Secretaria de Vigilância em Saúde. Departamento de DST, Aids e Hepatites Virais. Bol Epidemiol Aids/DST [Internet]. Brasília: MS, 2016[cited 2017 Aug 18]. Available from: http://www.aids.gov.br/sites/default/files/anexos/ publicacao/2015/58534/boletim_aids_11

23. Wu E, Galaz MI, Larrañaga C, Chávez A, González M, Álvarez AM, et al. Infección por VIH/SIDA en niños y adolescentes: cohorte chilena 1987-2014. Rev Chilena Infectol [Internet]. 2016 [cited 2017 Aug 14];33(Supl-1):11-19 Available from: http://www.scielo. $\mathrm{cl} / \mathrm{pdf} / \mathrm{rci} / \mathrm{v33s1/art02.pdf}$

24. Gómez-Ríos AC, Carrillo-Rozo ME, Rodríguez-Ortiz JA. Morbimortalidad materno-perinatal en pacientes con infección por 
VIH, Hospital Simón Bolívar, 2003-2011, Bogotá (Colombia). Rev Colomb Obstet Ginecol [Internet]. 2014 [cited 2017 Aug 14];65(4):308-16. Available from: http://www.scielo.org.co/pdf/rcog/v65n4/v65n4a04.pdf

25. Garcia G. Cuerpo y narrativa: una aproximación etnográfica al proceso de atención del embarazo, parto y puerperio de mujeres viviendo con vih en la ciudad de Buenos Aires. Horiz Antropol[Internet]. 2009 [cited 2017 Jun 02];(5)32:247-72. Available from: http://www.scielo.br/pdf/ha/v15n32/v15n32a11.pdf

26. Parham L, Murillo W, Rivera IL. Resistencia del VIH en mujeres embarazadas de Honduras durante el año 2015. Rev Cienc Tecnol[Internet]. 2016 [cited 2017 Jun 02]. Available from: http://lamjol.info/index.php/RCT/rt/metadata/2995/

27. Rodrigues NO, Neri AL. Vulnerabilidade social, individual e programática em idosos da comunidade: dados do estudo FIBRA, Campinas, SP, Brasil. Ciênc Saúde Colet [Internet] 2012 [cited 2017 Jun 02] 17(18):2129-39. Available from: http://www.scielo. $\mathrm{br} / \mathrm{pdf} / \mathrm{csc} / \mathrm{v} 17 \mathrm{n} 8 / 23 . \mathrm{pdf}$

28. Campos CGAPC, Sonara LE, Santos VS, Lazzarotto AR. A vulnerabilidade ao HIV em adolescentes: estudo retrospectivo em um Centro de testagem e aconselhamento. Rev Min Enferm[Internet]. 2014 [cited 2017 May 22];18(2):310-4. Available from: http:// www.reme.org.br/artigo/detalhes/929

29. Castro MG, Abromavay M, Silva LB. Juventude e Sexualidade. Brasília: UNESCO; 2004.

30. Oliveira TC, Carvalho LP, Silva MA. O Enfermeiro na atenção à saúde sexual e reprodutiva dos adolescentes. Rev Bras Enferm[Internet] 2008[cited 2017 Oct 02];61(3):306-11. Available from: http://www.redalyc.org/html/2670/267019606004/

31. Brasil. Ministério da Saúde, Secretaria de Vigilância em Saúde, Programa Nacional de DST e AIDS. Boletim Epidemiológico AIDS e DST [Internet]. Brasília: Ministério da Saúde; 2015 [cited 2017 May 29]. Available from: http://www.aids.gov.br/sites/default/ files/anexos/publicacao/2015/58534/boletim_aids_11_2 015_web_pdf_19105.pdf

32. Brasil. Ministério da Saúde. Secretaria de Políticas de Saúde. Assistência em Planejamento Familiar: manual para o gestor. Brasília: Ministério da Saúde; 2002.

33. Langendorf TF, Padoin SMM, Vieira LB, Mutti CF. Gestantes que tem HIV/Aids no Contexto da Transmissão Vertical: visibilidade da Produção Cientifica Nacional na Área da Saúde. Rev Pesq Cuid Fund[Internet]. 2011[cited 2017 May 29];3(3):2109-25 Available from: http://www.redalyc.org/pdf/5057/505750889026.pdf

34. Brasil. Ministério da Saúde, Secretaria de Vigilância em Saúde, Programa Nacional de DST e AIDS. Bol Epidemiol AIDS e DST [Internet]. Brasília: Ministério da Saúde; 2015 [cited 2017 May 29] Available from: http://www.aids.gov.br/sites/default/files/ anexos/publicacao/2015/58534/boletim_aids_11_2 015_web_pdf_19105.pdf

35. Brasil. Decreto $n^{\circ}$. 6.286, de 5 de dezembro de 2007. Institui o Programa Saúde na Escola - PSE, e dá outras providências. Feminização da AIDS e adolescência[Internet]. Diário Oficial da União, 6/dez/2007 [cited 2017 Oct 02]. Available from: http:// www2.camara.leg.br/legin/fed/decret/2007/decreto-6286-5-dezembro-2007-565691-norma-pe.html

36. Riscado JLS, Oliveira MAB, Brito ÂMB. Vivenciando o racismo e a violência: um estudo sobre as vulnerabilidades da mulher negra e a busca de prevenção do HIV/Aids em comunidades remanescentes de Quilombos, em Alagoas. Rev Saude Soc[Internet]. 2010 [cited 2017 Oct 02];19(2). Available from: http://www.scielo.br/pdf/sausoc/v19s2/10.pdf

37. Santos NJS. Mulher e negra: dupla vulnerabilidade às DST/HIV/Aids. Saude Soc[Internet]. 2016 [cited 2017 May 29];(25)3:602618. Available from: http://www.scielo.br/pdf/sausoc/v25n3/1984-0470-sausoc-25-03-00602.pdf

38. Brasil. Ministério da Saúde. Protocolo Clínico e Diretrizes Terapêuticas para Manejo da Infecção pelo HIV em Crianças e Adolescentes [Internet]. Brasília: Ministério da Saúde; 2014 [cited 2017 Jun 02]. Available from: http://www.aids.gov.br/sites/ default/files/anexos/publicacao/2013/55308/protocolofinal_31_7_2015_pdf_31327.pdf

39. Reis RK, Santos CB, Gir E. Quality of life among Brazilian women living with HIV/Aids. AIDS Care [Internet]. 2012 [cited 2017 May 17];24(5):626-34. Available from: http://www.tandfonline.com/doi/pdf/10.1080/09540121.2011.630345

40. Alagoas. Secretaria de Estado da Saúde. Superintendência de Gestão e Participação Social. Plano Estadual de Saúde do Quadriênio 2012-2015 (PES 2012-2015)[Internet]. Maceió: SESAU/AL; 2012 [cited 2017 Oct 02]. Available from: http://www.saude.al.gov.br/ wp-content/uploads/2016/03/PES_2012_2015.pdf

41. Reis CT, Czeresnia D, Barcellos C, Tassinari WS. A interiorização da epidemia de HIV/Aids e o fluxo intermunicipal de internação hospitalar na Zona da Mata, Minas Gerais, Brasil: uma análise espacial. Cad Saúde Pública[Internet]. 2008 [cited 2017 May 29];24(6):1219-28 Available from: http://www.scielo.br/pdf/csp/v24n6/03.pdf

42. Silva MAP, Menezes RCE, Oliveira MAA, Silva GL, Asakura L. Atenção Básica em Alagoas: expansão da Estratégia Saúde da Família, do Nasf e do componente alimentação/nutrição. Saúde Debate [Internet]. 2014 [cited 2017 Oct 02];38(103):720-32. Available from: http://dx.doi.org/10.5935/0103-1104.20140066

43. Konopka CK, Beck ST, Wiggers D, Silva SK, DiehI FP, Santos FG. Perfil clínico e epidemiológico de gestantes infectadas pelo HIV em um serviço do Sul do Brasil. Rev Bras Ginecol Obstet [Internet]. 2010 [cited 2017 May 29];32(4):184-90 Available from: http:// www.scielo.br/pdf/rbgo/v32n4/v32n4a06.pdf

44. Lima AC, Costa CC, Teles LM, Damasceno AK, Oriá MO. Epidemiologic assessment of prevention of vertical transmission of HIV. Acta Paul Enferm [Internet]. 2014 [cited 2017 Apr 21];27(4):311-8. Available from: http://www.redalyc.org/html/3070/307031738005/

45. Romanelli RMC, Kakehasi FM, Tavares MCT, Melo VH, Goulart LHF, Aguiar RALP, et al. Perfil de gestantes infectadas pelo HIV. 
Rev Bras Saúde Matern Infant [Internet]. 2006 [cited 2017 Jun 29];6(3):329-34 Available from: http://www.scielo.br/pdf/rbsmi/ v6n3/31904

46. Brasil. Ministério da Saúde. Secretaria de Atenção à Saúde. Gestação de Alto Risco: manual técnico. 5a ed. Brasília: SAA; 2012 [cited 2017 Aug 02]. Available from: http://bvsms.saude.gov.br/bvs/publicacoes/manual_tecnico_gestacao_alto_risco.pdf 26

47. Brasil. Ministério da Saúde. Portal de Saúde. Pactuadas novas metas mundiais para o enfrentamento ao HIV/Aids [Internet]. 2016[cited 2017 Oct 01]. Available from: http://portalsaude.saude.gov.br/index.php/cidadao/principal/ agencia-saude/24088-pactuadas-novas-metas-mundiais-para-o-enfrentamento-ao-hiv-aids

48. Cartaxo CMB. Gestantes portadoras de HIV/AIDS: aspectos psicológicos sobre a prevenção da transmissão vertical. Estud Psicol [Internet]. 2013 [cited 2017 Out 01]18(3):419-27. Availabe from: http://www.scielo.br/scielo.php?script=sci_arttext\&pid=S1413294X2013000300002

49. Lima AC, Costa CC, Teles LMR, Damasceno AKC, Oriá MOB. Avaliação epidemiológica da prevenção da transmissão vertical do HIV. Acta Paul Enferm [Internet]. 2014 [cited 2017 Out 02];27(4):311-8. Available from: http://www.scielo.br/pdf/ape/v27n4/ en_1982-0194-ape-027-004-0311.pdf

50. Leite AMAL, Vieira NFC, Silva RM. Implementação do diagnóstico da infecção pelo HIV para gestantes em Unidade Básica de Saúde da Família em Fortaleza, Ceará. Ciênc Saúde Colet[Internet]. 2008[cited 2017 Sep 26];13(6):1899-906. Available from: http://www.scielo.br/pdf/csc/v13n6/a25v13n6.pdf 